\title{
Pierre-François Olive Rayer: Biography
}

Writing in 1932, Dr. Raymond Molinéry described the renowned French physician Pierre-François Olive Rayer (1793-1867) as having had the misfortune to have been born and to have lived through tempestuous times, when intrigue and violent uprisings were happy bed-fellows. It would seem appropriate then, before setting out details of the life and professional achievements of this "good, gentle, affable and dignified man", , to pause briefly and consider the general tenor of that period in the history of France. How unsettled was the political climate in those years through which Rayer lived and worked so energetically? Those years, in which he devoted himself tirelessly to his professional life and medical researches, left a fine legacy to future generations of physicians. As Molinéry put it, "The history of the life and work of Rayer? This is a complete chapter in the History of Medicine."2 Some might level a critical "hagiography not biography!" at statements such as this, but it is hard to encounter any truly adverse comment in most accounts of Rayer's life and work, and surely none would contest the undoubted scholarship of this remarkable man.

Rayer graduated in 1818, three years after the second reinstatement of the Bourbon monarch Louis XVIII, whose determination to rule constitutionally was frustrated by both the Ultra-Royalists on the right and the Republicans on the left. Both factions were determined to overthrow the existing regime in furtherance of their own interests. In 1824 the succession of Louis's brother, Charles X, allowed the "Ultras" to gain complete control: the liberal charter of 1814 was virtually repealed, the land settlements of the Revolution were openly challenged and the press vigorously censored. In 1830 Charles dissolved the Chambers; when the new elections went against him he issued the celebrated Four Ordinances of St. Cloud. Thus the new parliament was dissolved even before its inaugural meeting, the liberty of the press was suspended indefinitely and the franchise was further restricted. The people's answer to such repressive and reactionary measures was rioting and the erection of the barricades in Paris on 28th, 29th and 30th July, "les Trois Glorieuses". This brought an effective end to the Restoration.

Louis Philippe's reign from 1830 to 1848 brought similar problems. Many people were deprived of their livelihood as the Industrial Revolution spread rapidly across France, and this again led to rioting in many major cities. The constitutional and political changes born of the successive regimes that governed France during Rayer's lifetime gave scant encouragement to the scientist, particularly since research in this field was grossly undervalued. This was particularly so during the reign of Napoleon III who, in his supreme autocracy, held the entire executive power in his own hands, with the Senate and the Legislative Body left virtually impotent. The Council of State was nominated by him, as were the Prefects and the Mayors, who were made directly responsible to him. The press was controlled and the universities were supervised. As history has shown us, intellectuals always pose a threat

\footnotetext{
${ }^{1}$ Raymond Molinéry, La vie et l'oeuvre de Rayer, Paris, Médical, 1932, pp. 439-40.

${ }^{2}$ Ibid., p. 439.
} 


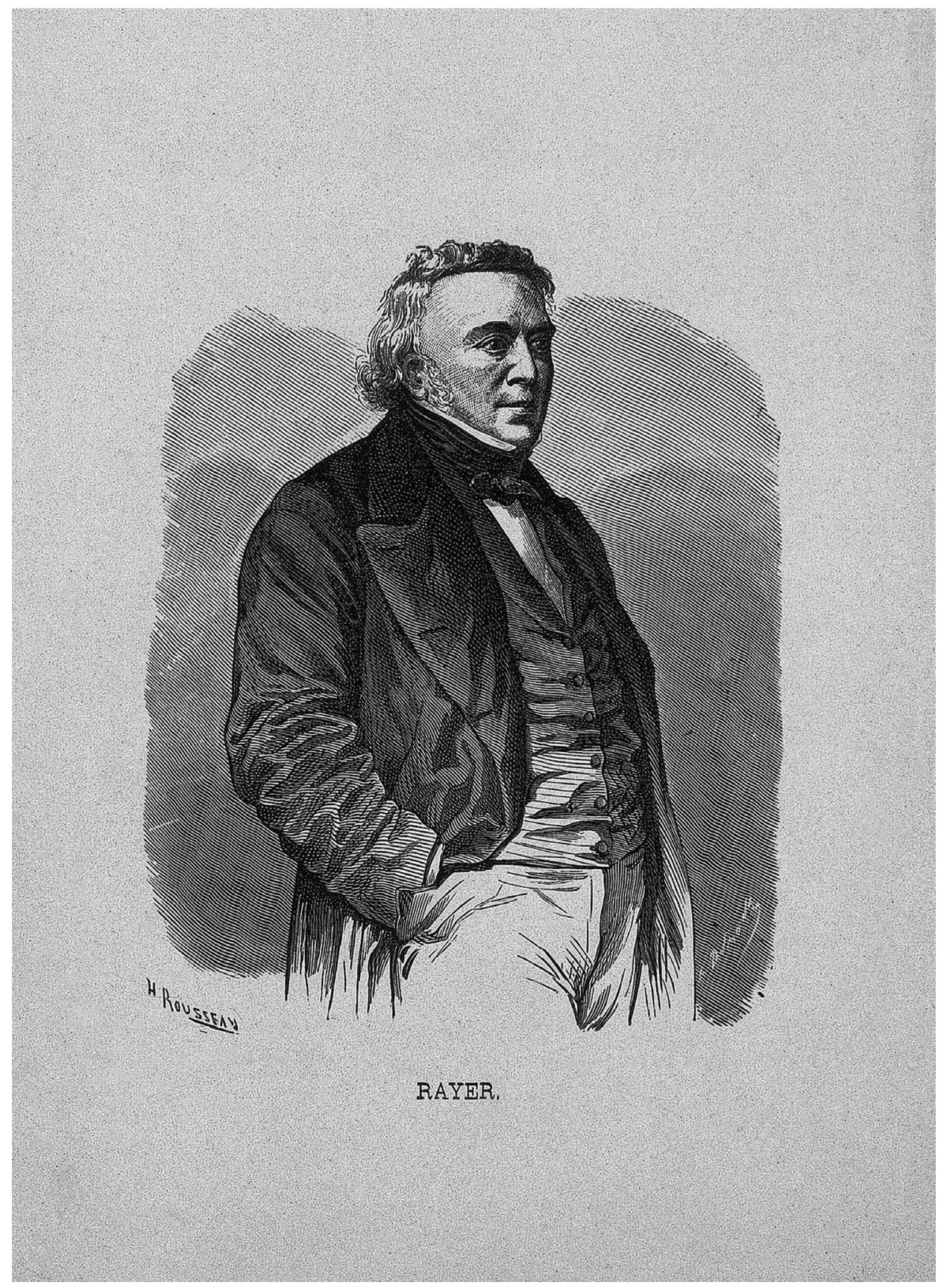

Pierre-François Olive Rayer (1793-1867). Wood engraving by L Desgodetz after H. Rousseau. 


\section{Pierre-François Olive Rayer: Biography}

to autocracy, thus the innovative thinkers and scientists were suppressed and marginalized. It says much for the individual who can find the determination to continue and to succeed in such hostile circumstances.

Pierre-François Olive Rayer was born in Saint Sylvain near Caen, in the Department of Calvados, in 1793. Here we find a street named in his honour but otherwise little trace of his family. He went to Paris to study medicine and in 1812, whilst still a student, he went with five other colleagues to Dijon, where he helped care for Spanish prisoners who were suffering from typhus. In 1813 he became a hospital intern, having been nominated laureate of l'École Pratique and winning prizes in both Chemistry and Anatomy, two disciplines which he always considered to be the bedrock of clinical medicine.

In 1814, as a student of André-Marie C. Duméril, Rayer devoted himself to the study of morbid anatomy and clinical medicine based on observation. In 1818 he presented his doctoral thesis entitled 'Sommaire d'une histoire abrégée de l'anatomie pathologique', which may be seen as the precursor to his later work in the field of medical history. The concepts presented in this vast historical panorama were traditional, non-polemical and might be criticized for taking few risks. However, the work was clearly influenced by the teachings of his professor, Duméril: it was erudite, eclectic and displayed a pleasing liberty of thought. It was Duméril's influence that led to Rayer's interest in comparative pathology.

In his day-to-day duties as a medical assistant Rayer was a keen devotee of morbid anatomy for he realized that his findings at post-mortem examination would support both his work and his publications. Yet despite his deep interest in the subject, Rayer was never involved in the institutionalization of pathological anatomy as a separate subject or faculty and his name never appeared on the list of the founding members of the Société Anatomique of Paris of which Jean Cruveilhier was the Perpetual President. Neither was his name listed in the Bulletin de la Société Anatomique. Rayer did, however, later become the first President of the Société de Biologie, which he founded with Claude Bernard, CharlesPhilippe Robin, Charles Edouard Brown-Séquard, François Follin and Charles-Nicolas Houel in 1848. Cruveilhier, Prost and Gabriel Andral wrote several treatises, atlases and précis on morbid anatomy but Rayer left only the one work, his doctoral thesis, which none the less provided a wealth of historical material. Rayer's contribution to the field of morbid anatomy was not unique, for the 1830s saw a growth in the use of such techniques. His contribution provided rather more than the mere institutionalization of the discipline however, for he was instrumental in developing the role of comparative anatomy through the expansion of the topic within his own work and by the creation of a Chair of Comparative Anatomy, or Pathology as it later became known. He also defended and promoted the use of the microscope in pathological studies.

Rayer's deep interest in the disciplines of both anatomy and pathology led him to become something of a pioneer in the field of infectious diseases. In 1821 he was sent by the Ministry of Instruction as part of the Medical Commission to observe and report on an epidemic of miliaria that was ravaging the countryside around l'Oise: this led to the publication, in 1822, of a monograph on that topic. It was a disappointment for Rayer when he was denied permission to go to Barcelona to observe an epidemic of yellow fever, but he did translate a report on the disease from the original Spanish. Rayer was an excellent observer. He was also a perspicacious epidemiologist and could be deemed 


\section{The History of Albuminous Nephritis}

the precursor of the great bacteriologists of later decades. He carried out innovative work on glanders, anthrax (in 1850 he identified under the microscope the Bacillus anthracis) and murrain and on pulmonary phthisis in humans, mammals and birds. Particularly interesting is a discussion on medical statistics, presented to the Academy of Medicine in 1836, which was an appeal for the quantification of some elements of his medical observations for comparative purposes, the better to appreciate the effects of various medicines and treatments.

Although Rayer wanted to stay in academic medicine and follow a career as a clinical teacher this was at the time denied to him because of his marriage to a Protestant. He saw his name removed from the list of candidates for the traditional "concours de l'agrégation" by Abbé de Frayssinous, then Minister of Public Instruction, apparently as a punishment for having done so. As a result he built up a large private practice for mainly wealthy Protestants and Jews. However, in 1823, at thirty years of age, he was honoured with an appointment as Assistant Physician at the Academy of Medicine, followed by other equally respected appointments as doctor of the Central Bureau and subsequently as doctor at l'hôpital St Antoine in 1824 and 1825 respectively, finally taking up a position in 1832 at l'hôpital de la Charité, where he remained until his retirement.

In 1826-7 Rayer published his superb work on skin diseases, Traité théorique et pratique des maladies de la peau. The work was received with great acclaim and was translated into Italian by Professor Giambattista Fantonetti in 1830 and into English in 1833 by Dr. W. B. Dickinson. This masterly piece of research is the first on the subject that might be considered "modern", particularly the fine second edition of 1835 presented in three volumes of some 1,700 pages, including an atlas with the most wonderful original plates. Here we find descriptions of warts and skin cancers that are mentioned only briefly, if at all, in other contemporary texts. This work unites Rayer's great personal qualities of clinical observation and critical utilization of the best contributions to the field made by his predecessors. Although no skin disease bears the Rayer eponym (Willan and Bateman's classifications had already been accepted) he did make some original contributions to this field of study among which were a proposed division between acute and chronic eczema and similarly between acute and chronic ecthyma. In addition, his chapter on syphilis and syphilides, as he names the manifestations of the disease, shows that he was one of the first to recognize skin lesions as markers of underlying systemic diseases-for example he described blenorrhagia as a sign of syphilis. ${ }^{3}$

After the Revolution of 1830 public honours were restored to Rayer and under Louis Philippe he became Physician to the King, to the Prince-Président, to the Duc de Morny, the Princess Mathilde and eventually to the Emperor Napoleon III. By that time, rather like his contemporary Dr. Richard Bright in London, he had become one of the most fashionable doctors in Paris. The care of his patients could never entirely divert him from his scientific research, however. It was at this stage in his career that he began to devote himself to the study of renal disease. Most of his work in this field was undertaken at l'hôpital de la Charité.

In 1827 Bright published his magnum opus, Reports of medical cases, described by Pierre-Eugène Menetrier in 1927 as "a ray of light in this obscure question of renal

${ }^{3}$ Pierre-Eugène Menetrier, 'Rayer, 1793-1867', Progrès Médical, 1927, pp. 989-97. 


\section{Pierre-François Olive Rayer: Biography}

disease". In 1839 Rayer's long awaited Traité des maladies des reins, with its accompanying atlas of fine coloured plates, was published. In the judgement of E. Lecorche and Ch. Talamon it was, "by the fullness of its documentation, the richness of its clinical details, the accuracy of its ideas, the most remarkable work after that of Bright". 5 The work was translated into German by G. Krupp but, sadly, not into English. This current translation of one small section, 'The history of albuminous nephritis', we hope bears testimony to Rayer's outstanding scholarship. Further support comes in the words of a renowned French nephrologist of today for, in the opinion of Professor Gabriel Richet, if only the table of contents of the Traité had been read then clinical nephrology would have progressed at a very different pace. Praise indeed, but we should not ignore the fact that one of Rayer's contemporaries, the Irish physician Robert Graves, was not without criticism of "the latest and most elaborate treatise" that had appeared from the "pen of the celebrated Rayer". He sets out his objections in Lecture LIV of his Clinical lectures. Graves feels that Rayer

... has brought forward a great number of facts, but he seems to me not to have been guided by logical precision in his inductions. Without questioning the accuracy of his observations, I feel called upon to protest against several of his conclusions and cannot help feeling that his treatise exhibits internal evidence of inconsistency. The whole object of his work is to account for certain symptoms, by showing that they are caused by a morbid change in the structure of the kidneys, which he terms albuminous nephritis. The investigations of the morbid anatomist, when legitimately pursued, lead to positive facts, not liable to be misinterpreted or confused, and which ought, in every instance, to be studied of and for themselves. The results of such investigations should be positive and palpable, for in order to investigate the real nature of the changes observed in any organ, an observation is worth nothing, unless what we see in the dead body distinctly discloses the nature of those changes.

Graves goes on to point out that the true object of morbid anatomy is to "invert the hitherto received method of that science, making us explain structural changes by symptoms, and not symptoms by structural changes". ${ }^{6}$ Whilst it would be inappropriate in this short biographical sketch to include further quotation from Graves's lecture, the interested reader may well wish to explore further and, indeed, reach his/her own conclusions as to the scientific value of Rayer's work.

It was in the early 1830s that Rayer turned his attention to diseases of the kidneys and during this period many articles and theses appeared for which he had clearly been the inspiration. These were written by many of the young doctors such as J. V. Bureau, A. Desir, Charles Polydore Forget, Jean-Louis Genest, J. C. Sabatier, Edouard Tissot, Eugène Vigla, etc. who were either working, or had at some time worked, in his service.

Rayer's contribution to the semiology of nephritis was undoubtedly aided by the use of the microscope, a piece of equipment he so favoured that he installed one in his service that would be readily accessible to the interns twenty-four hours a day. Thus Rayer was one of the first to gather "in vivo" the histological information/data relating to renal pathology. He was particularly interested in studying urine under the microscope for he recognized its

\footnotetext{
${ }^{4}$ Les Biographies médicales, ed. P. Busquet, 5 vols, Paris, J.-B. Baillière, 1932-1934, vol. 5, pp. $33-48$.

${ }^{5}$ Ibid., pp. 36-7.

${ }^{6}$ Robert Graves, Clinical lectures on the practice of medicine, Dublin, Fannin, 1864, p. 265.
} 


\section{The History of Albuminous Nephritis}

value as an indicator of activity in the kidney itself. ${ }^{7} \mathrm{He}$ was not very interested in the terminal stage of chronic nephropathy, later studied so completely by Robert Christison in 1839. He was always more orientated towards the initial stages of a disease rather than its termination, in the hope of recognizing the cause or underlying mechanism. After the publication of Traité des maladies des reins Rayer was drawn towards comparative pathology and transmissible diseases and he published no further work on nephrology.

In 1842 Rayer was persuaded to accept the Chair of Rural Economy in recognition of his important work on disease in animals. This was something of a political appointment, since originally there was a possibility that Rayer would replace Double at the Academy of Science Medical Section. However, Andral was also keen to secure that post and, if Labarthe can be believed, in order to avoid any problems, Andral's friends suggested to Rayer's that his appointment to the Chair of Rural Science would pass uncontested. ${ }^{8}$

Rayer had become a symbol for those, particularly the younger generation, who had faith in the future of science. It is not surprising, therefore, that Rayer should become a founder member and indeed President of the Société de Biologie set up in 1848 in Paris to provide a "periodical meeting where physicists, chemists, naturalists and doctors could gather and discuss together all natural phenomena". 9 The Society owed much to Rayer; he gave it its scientific impulse and its legal existence. Other friends and colleagues, such as Claude Bernard, Auguste Chomel and his former "opponent" Andral, were also members. Rayer was also instrumental in having Richard Bright elected to this august body.

Many further honours followed in his later years: in 1857 he became President of the Consultative Committee on Public Hygiene, in 1859 he was made first President of l'Association Générale des Médecins de France, which he had been instrumental in creating, and finally, in 1862, he achieved his long awaited ambition to become Professor of Comparative Medicine of the Faculty of Medicine in Paris. He made many improvements during his tenure here but unfortunately his deanship was of short duration. At that time the faculty deans were Government nominees, regarded with some suspicion as agents emplaced to control the latent, and at times explosive, agitation of the student body. Despite being well-known for his liberal views, Rayer's background as physician to first King Louis-Philippe and then the Emperor, his wealthy private clientele composed of the most powerful in society, plus the fact that he had not even been aggregated, meant that he was treated as an impostor and his deanship lasted a bare eighteen months.

By 1867 Rayer's health had begun to deteriorate. During the night of 8 September he suffered a stroke; he was cared for by Casimir-Joseph Davaine but died forty-eight hours later in his home at 14 rue de Londres, where he had lived for many years.

Rayer had always been acquainted with many of the most prominent people of his time and particularly with Dominique François Jean Arago, Henri Hureau de Senarmont, Henri Becquerel, Claude Bernard, Michel Eugène Chevreul and Payen to name but a few. He was often criticized for his devotion to and active patronage of his friends and students, but

\footnotetext{
${ }^{7}$ Pierre-François Olive Rayer, Traité des maladies des reins et des altérations de la sécrétion urinaire, 3 vols, Paris, J.-B. Baillière, 1837-41, vol. 1.

${ }^{8}$ Les Biographies médicales, vol. 5, pp. 33-48.

${ }^{9}$ Ibid., p. 37.
} 


\section{Pierre-François Olive Rayer: Biography}

when one considers that amongst the latter were names such as Émile Littré, Robin, Brown-Séquard, Jean-Martin Charcot, Adolphe Marie Gubler and Davaine one is bound to admit the truth of $\mathrm{C}$. Hillemand's description of him as being "a true discoverer of men". 10

Remembering the difficulties he had himself encountered at the outset of his career he supported those in whom he recognized positive qualities and strength of purpose. Littré often told of how Rayer had lent him the necessary monies to set him on the path to becoming a doctor.

Rayer's output was, as we have seen, quite considerable, his works encompassing pathological anatomy, physiology, human pathology, epidemiology, therapeutics, comparative pathology and natural history. The driving force behind his work and the diversity of subjects that he addressed was a belief in the fundamental universality of the science of organized life forms. He believed that the study should not be limited to one life form only but should encompass life in its entirety-all life forms, vegetable as well as animal, should come within the domain of this new science. Such concepts took hold and blossomed post Rayer, but we may regard him as having laid the foundation for what Amédée Latour, Director of l'Union Médicale, described as "the pantheism of biological science". 11

\footnotetext{
${ }^{10}$ Ibid., p. 44.

${ }^{11}$ Jean-Raimond-Jacques-Amédée Latour (1805-1882), 'Eloge de Rayer', Annuaire Association générale de prévoyance et de secours mutuels des médecins de France, 1868: 70-105, Union médicale, 1867, vol. 3, pp. 435, 450, 458. See also published papers of the Société française d'histoire de la médecine, seminar held on 25 May 1991 dedicated to Pierre-François Olive Rayer.
} 